Table 1. Gamma-spectrometric assays of radioactive elements in hand samples compared with c. p. s. levels from the airborne survey

\begin{tabular}{lcccccc}
\hline Rock type & $\mathrm{U}(\mathrm{ppm})$ & $\mathrm{Th}(\mathrm{ppm})$ & $\mathrm{K}(\%)$ & $\mathrm{U}$ (c.p.s.) & T (c.p.s.) & $\mathrm{K}$ (c.p.s.) \\
\hline $\begin{array}{c}\text { Charcot Bugt Sandstone, } \\
\text { not mineralised } \\
(1 \text { sample })\end{array}$ & 0.84 & 6.28 & 1.02 & $5-10$ & c. 25 & c. 30 \\
\hline $\begin{array}{c}\text { Charcot Bugt Sandstone, } \\
\text { mineralised } \\
\quad(10 \text { samples })\end{array}$ & 160 & 627 & 1.61 & $20-40$ & $70-90$ & c. 30 \\
\hline $\begin{array}{c}\text { Granitic basement } \\
(3 \text { samples })\end{array}$ & 1.65 & 8.22 & 2.42 & c. 10 & $25-30$ & $40-50$ \\
\hline
\end{tabular}

apparent drastic changes along the flight line compared to the apparently smoother changes in the plots of the element activities. This is explained by an insufficient statistical significance of the count rates in the $\mathrm{U}, \mathrm{T}$ and $\mathrm{K}$ channels, exaggerated when the ratios are calculated.

\title{
References
}

Håkansson, E., Birkelund, T., Heinberg, C. \& Willumsen, P. 1971: Preliminary results of mapping the Upper Jurassic and Lower Cretaceous sediments of Milne Land. Rapp. Grønlands geol. Unders. 37, 32-41.

Nielsen, B. L. 1972: Aeroradiometric survey in the Scoresby Sund region, East Greenland. Rapp. Grønlands geol. Unders. 45, 42-43.

L. L.,

Danish Atomic Energy Commission,

Research Establishment Risø,

4000 Roskilde.

\section{GENERAL COMPILATION OF ISOTOPIC WORK ON ROCKS FROM GREENLAND}

\section{Compiled by David Bridgwater}

1972 has seen a further development of the trend noted in Report of Activities, 1971 towards detailed isotopic studies of particular petrological and geochronological problems rather than the regional programmes of $\mathrm{K} / \mathrm{Ar}$ mineral age determinations carried out previously. As the main picture of Greenland geochronology emerges so the problems to be solved become more complex and require close 
cooperation and mutual understanding between field and the laboratory investigators. In many studies the limits of the currently available field and laboratory techniques have been reached and in several cases now under investigation interpretation of the results involves a much more exact knowledge of the conditions under which the various rock and mineral systems become closed to loss of radiogenic daughter elements.

Isotopic studies of such complexity are at least for the foreseeable future beyond the resources of the Survey both in man-power and instrumentation and it is clearly uneconomical at this time for the Survey to build up its own facilities for age determination. On the other hand the time when teams of geochronologists could usefully go into an area and sample independently of the main geological parties working on the ground is fast coming to a close and as a policy the Survey therefore welcomes cooperation with other institutions which wish to study particular problems in Greenland. Cooperation ranges from giving advice to independent groups about the most suitable sites to collect material, to providing field facilities and some funds for laboratory work in cases where the results have a direct bearing on the field investigations being carried out by the Survey.

The number of institutions now wishing to work on Greenland material has increased sharply in the last three years and there is now a much more general appreciation outside Denmark that Greenland geology offers unique petrological and geochronological problems in areas where field geologists have established relationships between the major rock units but which have not been studied adequately in the laboratory. This increase of interest makes it impossible for the Survey to provide field support for every group wishing to carry out geochronological studies, because firstly we lack the logistical capacity to supply more than two or three specialist parties per year and secondly, with an area as large and complex as Greenland our policy is not to support more than one group in any one particular area. In practice therefore the Survey is more likely to offer support to outside institutions who wish to work in areas where Survey field parties are active but which lack geochronological control or to institutions which can work on material already collected for geochronologic studies by Survey field parties.

Summary of investigations now in progress or published in 1972

The ages reported here have been published, are in press, or have been released at public meetings either by the geochronologists involved or the field workers from whom the samples were obtained. Where preliminary results are reported these should be taken as an indication of work in progress rather than providing fixed points in the geochronology of Greenland.

\section{(1) Basic dykes and sills in the Thule district, North Greenland}

K/Ar studies have been carried out by D. C. Rex (Univ. of Leeds) on basic 
sills and dykes from the Thule area collected by P. R. Dawes and H. F. Jepsen (see Dawes et al., this report). Although the majority of samples obtained from these igneous rocks show signs of alteration either due to deuteric processes or later metamorphism it was thought worth while attempting to obtain a minimum age for the date of their intrusion since they post-date an important group of flat-lying sediments in the area, the age of which has variously been ascribed to the Palaeozoic, the Eocambrian and the Proterozoic. The ages obtained from the basic rocks cutting them are all older than $532 \mathrm{~m}$.y., with one group of the sills giving ages between 1000 and $1200 \mathrm{~m}$.y. suggesting that the sediments are Proterozoic.

\section{(2) Dyke rocks in the Umanak area, northern West Greenland}

Henderson (1973) discusses the significance of two NNW-trending basic dykes which extend for over $400 \mathrm{~km}$ in the Umanak area, the intrusion of which is thought to be related to the opening of the Davis Strait. O. Larsen (Univ. of Copenhagen) has carried out several K/Ar determinations on samples from one of these dykes; unfortunately these have yielded apparent ages in excess of 2000 m.y., which is older than the regional $\mathrm{K} / \mathrm{Ar}$ mineral ages obtained from the surrounding gneisses. It is clear that the dyke rocks contain large amounts of excess argon.

\section{(3) Basement rocks in the Nagssugtoqidian and Rinkian mobile belts}

The area of Precambrian gneisses north of S $\varnothing$ ndre Strømfjord which gives a regional K/Ar age of approximately 1700 m.y. (Larsen \& Møller, 1968) has been subdivided geologically into two units: the area south of Jakobshavn consisting essentially of Archaean granitic gneisses reworked in the Nagssugtoqidian tectonic and metamorphic events (see Escher et al., in press) and the area north of Jakobshavn which consists of an older presumed Archaean basement overlain by a major group of metasediments (Henderson \& Pulvertaft, 1967) which has now been given the name the Rinkian mobile belt. Material for $\mathrm{Rb} / \mathrm{Sr}$ whole rock and $\mathrm{U} / \mathrm{Pb}$ age determinations has been collected from blast sites in both areas and it is hoped that laboratory investigations either in Copenhagen or outside institutions will be started in the near future.

\section{(4) Volcanic activity in the West Greenland Tertiary province}

The lower part of the Tertiary volcanic lavas and ash layers contain several units the stratigraphic age of which is well controlled by palaeontological determinations on the accompanying sediments. $\mathrm{K} / \mathrm{Ar}$ age determinations on the volcanic rocks (O. Larsen) have proved difficult due to (a) the presence of Precambrian basement fragments in the ash layers resulting in a spuriously high radiometric age for these rocks, and (b) the common occurrence of glass in the basement rocks which has proved to have poor retention of argon. Work is continuing in the hope of finding more suitable material. 
(5) Age of deformation in the Nagssugtoqidian mobile belt

$\mathrm{R}$. Chessex (Univ. of Geneva) has completed $\mathrm{U} / \mathrm{Pb}$ concordia studies on zircons separated from various units on either side of the Nagssugtoqidian boundary in West Greenland mapped by Escher et al. (1970 and in press) and has started work on a limited number of samples from the corresponding boundary in South East Greenland. The most significant feature of the results from West Greenland is that zircons separated from the rocks affected by extremely high Nagssugtoqidian deformation and granulite-facies metamorphism give the same isotopic age (within limits of experimental error) as the rocks south of the boundary which yield U/Pb concordia ages between 2800-2900 m.y. Recent field work (Bridgwater et al., this report) has suggested that the formation of the major shear zones and the injection of dykes used to separate "Nagssugtoqidian" events from "preNagssugtoqidian" events are closely related and could have occurred at approximately the same time as the late Archaean granulite-facies metamophism which occurred over much of West Greenland. 'The apparent lack of age difference in the zircons from either side of the boundary is therefore tentatively attributed to the difficulty in distinguishing two or more events separated by small time differences rather than being due to the resistance of the $\mathrm{U} / \mathrm{Pb}$ system in zircon to later much younger events. Chessex reports that the zircons from the highly deformed rocks show no evidence of a major thermal or tectonic event around 1700 m.y., the K/Ar age obtained for rocks in the Nagssugtoqidian mobile belt. Further investigations are planned on undeformed material collected in 1972 from major dykes affected to the north by Nagssugtoqidian movements.

(6) $U-T h-P b$ studies on zircons from the early Precambrian Amîtsoq gneisses of the Godthåb district, West Greenland.

H. Baadsgaard (Univ. of Alberta, Edmonton) has presented a manuscript* for publication giving U-Th-Pb concordia ages of $3650 \pm 50$ m.y. and $3648 \pm 85$ m.y. for 9 zircon fractions separated from 6 samples of Amîtsoq gneisses. Preliminary results of this work have been quoted (OIGL \& McGregor, 1971). Further U-Th$\mathrm{Pb}$ studies are in progress at Alberta on zircons separated from various of the pre-3100 m.y. supracrustal units found in the Godthåbsfjord area.

(7) Investigations in the ancient gneiss complex of West Greenland by the Oxford Age and Isotope Geology Laboratory (contributors: L. P. Black, N. H. Gale, S. Moorbath, R. K. O'Nions, R. J. Pankhurst)

The following is a brief summary of recently published, as well as unpublished but completed, isotopic age work on rocks from Godthåbsfjord and neighbouring areas of West Greenland. Some revision of the initially published $\mathrm{Rb} / \mathrm{Sr}$ age of $3980 \pm 170$ m.y. (OIGL \& McGregor, 1971) for the Amîtsoq gneisses has become necessary as the result of a great deal of further work.

* Baadsgaard (1973) 
(a) Amîtsoq gneisses, Godthåbsfjord area, and granitic gneisses from Isua (in collaboration with V. R. McGregor).

These results were obtained on the material collected by V. R. McGregor and S. Moorbath in 1971. Some of the data has already been published (Moorbath et al., 1972). All errors are given at the $95 \%$ confidence level. The half-life of ${ }^{87} \mathrm{Rb}$ is taken as $5.0 \times 10^{10} \mathrm{y}$.

(i) A 25-point $\mathrm{Rb} / \mathrm{Sr}$ whole-rock isochron from the Lille Narssaq area yielded a date of $3750 \pm 90$ m.y., with an initial ${ }^{87} \mathrm{Sr} /{ }^{86} \mathrm{Sr}$ ratio of $0.7015 \pm$ 0.0008 . Of the 25 analytical points, 4 had been published previously (OIGL \& McGregor, 1971).

(ii) A 7-point $\mathrm{Rb} / \mathrm{Sr}$ whole-rock isochron from Qilángârssuit yielded a date of $3740 \pm 100 \mathrm{~m}$. $\mathrm{y}$., with an initial ${ }^{87} \mathrm{Sr} /{ }^{88} \mathrm{Sr}$ ratio of $0.7009 \pm 0.0011$. One data point had been published previously.

(iii) An 18-point $\mathrm{Rb} / \mathrm{Sr}$ whole-rock isochron from Praestefjord and several adjacent areas gave a date of $3690 \pm 230$ m.y., with an initial ${ }^{87} \mathrm{Sr} /{ }^{86} \mathrm{Sr}$ ratio of $0.7001 \pm 0.0017$. 6 of the data points had been published previously.

(iv) A 12-point $\mathrm{Rb} / \mathrm{Sr}$ whole-rock isochron from the granitic gneisses of the Isua area gave a date of $3700 \pm 140$ m.y., with an initial ${ }^{87} \mathrm{Sr} /{ }^{86} \mathrm{Sr}$ ratio of $0.7011 \pm 0.0020$. The Isua area is approximately $150 \mathrm{~km}$ north-east of the above localities and demonstrates the area of very ancient rocks to be extensive.

(b) Nûk gneisses from Bjфrneфen and Sadelфen, Godthåbsfjord (Pankhurst et al., 1973).

The Nûk gneisses are a group of deformed, younger, dominantly tonalitic intrusions forming mappable units in the Godthåbsfjord gneiss complex (McGregor, 1973).

A 13-point Rb-Sr whole-rock isochron on samples supplied by V. R. McGregor yielded a date of $3040 \pm 50 \mathrm{~m} . \mathrm{y}$., with an initial ${ }^{87} \mathrm{Sr} /{ }^{68} \mathrm{Sr}$ ratio of 0.7026 \pm 0.0003 . The measured date is interpreted as the age of emplacement of the parent rocks of the Nûk gneisses.

(c) Anorthosites and associated pyroxene granulites from Nordland, Sukkertoppen and Fiskenaesset areas (in collaboration with B. F. Windley).

A 14-point ${ }^{206} \mathrm{~Pb} /{ }^{204} \mathrm{~Pb}$ vs ${ }^{207} \mathrm{~Pb} /{ }^{204} \mathrm{~Pb}$ whole-rock isochron comprising three anorthositic rocks and two pyroxene granulites from the Nordland area, three pyroxene granulites from the Sukkertoppen area, five anorthositic rocks and one pyroxene granulite from the Fiskenaesset area, yielded a date of $2850 \pm 100$ m.y. This is interpreted as the age of the granulite metamorphism which has affected all these rocks and is clearly comparable to the age of high-grade metamorphism in other parts of the Archaean North Atlantic Shield. This work is being prepared for publication. 
(d) Work in progress (January 1973)

(i) $\mathrm{Rb} / \mathrm{Sr}$ whole rock investigations on suites of basic dykes which cut the Amitsoq gneisses and their equivalents at Isua.

(ii) Similar studies on anorthosites of the Godthåbsfjord region.

(iii) $\mathrm{K} / \mathrm{Ar},{ }^{40} \mathrm{Ar} /{ }^{39} \mathrm{Ar}$ and $\mathrm{Rb} / \mathrm{Sr}$ investigations of separated minerals from the Amitsoq gneisses and their equivalents at Isua (in collaboration with G. Turner and D. C. Rex of the Universities of Sheffield and Leeds respectively).

(iv) $\mathrm{U} / \mathrm{Pb}$ and further $\mathrm{Pb} / \mathrm{Pb}$ age and isotope studies of the Amitsoq gneisses and their equivalents at Isua. Further material was collected from the Godthåbsfjord area in 1972 both from the gneiss units and various supracrustal units.

\section{(8) $\mathrm{Rb} / \mathrm{Sr}$ and $\mathrm{U} / \mathrm{Pb}$ studies in the Fiskenoesset area, West Greenland}

R. Pidgeon and his colleagues at the Scottish Universities Research and Reactor Centre are continuing their programme of $\mathrm{Rb} / \mathrm{Sr}$ whole rock and $\mathrm{U} / \mathrm{Pb}$ zircon determinations on the gneisses from the Fiskenæsset area. First results of this work are given in Pidgeon (1973) and report a U/ Pb concordia age of 3030 m.y. for a zircon separated from a granite formed at a relatively late stage in the geological development of the area. This has been interpreted as the age of formation of the granite which would suggest that a large proportion of the Fiskenæsset gneiss complex was earlier than 3000 m.y. old. However the current investigations by Pidgeon have shown that the geochronology of the area is very complex and geological interpretation must wait until much more material has been processed. Material was collected by the GGU team mapping Fiskenæsset in 1972 from the nunatak region, east of Frederikshaibs Isblink, where Dawes (1970) established a detailed stratigraphy comparable in complexity to that established by McGregor from Godthåbsfjord.

(9) $\mathrm{Rb} / \mathrm{Sr}$ whole rock investigations on the Fiskencesset anorthosite complex, West Greenland

Preliminary $\mathrm{Rb} / \mathrm{Sr}$ investigations by N. M. Evensen and V. R. Murthy (Univ. of Minnesota) on suites of rocks collected from the Fiskenæsset anorthosite complex were reported by B. F. Windley at the Royal Society meeting in London (1972). These rocks give a whole rock isochron of approximately 2900 m.y. (interpreted as the age of the high-grade metamorphism in the area) with one anomolous sample giving a possible indication that the original age of crystallisation of this body may have been considerable earlier.

(10) Gardar province, South Greenland

Van Breemen \& Upton (1972) report $\mathrm{Rb} / \mathrm{Sr}$ whole rock isochron ages from 
a group of intrusions ranging from $1245 \pm 16$ m.y. for the Kûngnât intrusion (Ivigtut area) to $1187 \pm 9$ m.y. and $1180 \pm 34$ m.y. for the Hviddal giant composite dyke and the Tugtutôq central complex respectively $(\lambda=1.39)$. Further work on Gardar intrusive rocks is in progress at the Scottish Universities Research and Reactor Centre in collaboration with B. G. J. Upton (Univ. of Edinburgh) and J. G. Anderson (Univ. of Aberdeen).

\section{(11) Ketilidian granitic rocks}

O. van Breemen and M. Aftalion (Scottish Universities Research and Reactor Centre) have completed their $\mathrm{Rb} / \mathrm{Sr}$ whole rock isochron and $\mathrm{U} / \mathrm{Pb}$ zircon studies of granitic rocks from the south-western part of the Ketilidian mobile belt, and a manuscript has been prepared for publication with J. H. Allaart. These writers report that early granites from the mobile belt have yielded $\mathrm{U} / \mathrm{Pb}$ ages of $1840 \pm$ $25 \mathrm{~m}$.y. Late granites form a well-defined group at $1780 \pm 20 \mathrm{~m}$.y. The U/Pb zircon results lie within the range of the experimental error of the $\mathrm{Rb} / \mathrm{Sr}$ whole rock isochron ages.

(12) Late orogenic granites and high-grade gneisses in the south and south-eastern parts of the Ketilidian mobile belt

B. L. Gulson and T. E. Krogh have continued their U/Pb studies on the highgrade rocks surrounding the late orogenic intrusive suites of South Greenland, at the Geophysical Laboratory of the Carnegie Institution of Washington (see Gulson \& Krogh, 1972). Gulson (pers. comm., 1972) reports that the ages obtained from zircon separated from some of the high-grade migmatite show a much greater spread than the results published in 1972 and that some of the zircon fractions retain isotopic histories of events earlier than 1830 m.y. Furthermore detailed studies of selected crystals of zircon extracted from the high-grade rocks close to the late orogenic suite of intrusions give isotopic ages similar to the late igneous suite. This is in agreement with the field evidence suggesting that the late intrusions were surrounded by a major thermal aureole (Bridgwater \& Watterson, 1967).

(13) Archaean rocks from the border zone of the Nagssugtoqidian mobile belt of South East Greenland

P. D. Nunes and R. H. Steiger (Eidg. Technische Hochshule, Zürich) have dated zircons from an inclusion of gabbro anorthosite collected from South-East Greenland (Nunes et al., in prep). The points obtained plot on a chord intersecting the concordia at 2700-2800 m.y. Further work is in progess on material collected in the border zone of the Nagssugtoqidian to help to resolve the problem as to whether the age obtained represents the original crystallisation of these rocks or a very strong metamorphic event. 


\section{(14) Scoresby Sund, East Greenland}

Two papers on the geochronology of hard rocks from the Scoresby Sund region have been published by GGU (report 48). Both report work done at the Eidg. Technische Hochschule, Zürich in cooperation with GGU.

Hansen et al. (1972) list $13 \mathrm{Rb} / \mathrm{Sr}$ mineral determinations from various rock units within the Caledonian fold belt. The presence of considerable pre-Caledonian basement material was confirmed from the Stauning Alper, Milne Land and Charcot Land with many of the rocks giving mineral ages over 700 m.y. B. T. Hansen and co-workers are continuing $\mathrm{Rb} / \mathrm{Sr}$ and $\mathrm{K} / \mathrm{Ar}$ mineral work on rocks from Scoresby Sund. They have also started $\mathrm{Rb} / \mathrm{Sr}$ whole rock isochron studies on the Krummedal and Charcot Land supracrustal rocks which should provide considerable insight into the general structure of the Caledonian fold belt.

Steiger \& Henriksen (1972) have published a progress report on $\mathrm{U} / \mathrm{Pb}$ zircon studies on three samples from the Scoresby Sund region. These yielded discordant $\mathrm{U} / \mathrm{Pb}$ ratios which lie on chords cutting the concordia curve at 2345 m.y., 1900 m.y. and 950 m.y. respectively, again confirming the presence of major amounts of Precambrian material in the Scoresby Sund region.

The 2345 m.y. age was obtained from a foliated granite collected from the Flyverfjord infracrustal basement complex and confirms earlier reports by Haller \& Kulp (1962) of reworked older rocks in the western part of the main Caledonian fold belt.

The 1900 m.y. result was obtained from a sample of hornblende-biotite quartz diorite from west Charcot Land which is thought to intrude rocks of the Charcot Land Series (Steck, 1971) but which is overlain by tillites. If the intrusive relationship reported by Steck applies to the whole body then this age must be regarded as a minimum age for the formation of the Charcot Land supracrustal rocks.

The 950 m.y. age was obtained from zircon separated from an augen granite forming part of a migmatitic central zone of the Caledonian fold belt in Nordvestfjord. The age obtained is interpreted as either the age of granite formation or a very powerful metamorphic event in the area, again showing that the rocks involved in Caledonian metamorphism commonly have a complex earlier history of high-grade metamorphism or plutonism.

Further $\mathrm{U} / \mathrm{Pb}$ studies on zircons and monazite separated from migmatites collected from Bjørneøer were reported by Oberli \& Steiger (1972) at the 2nd European colloquium of geochronology (Heidelberg, Sept. 1972). A minimum age of $445 \mathrm{~m} . \mathrm{y}$. for cooling below $650^{\circ} \mathrm{C}$ following the Caledonian metamorphism is reported from the monazite determinations. The $\mathrm{U} / \mathrm{Pb}$ measurements on zircons were discordant and do not fall on a single chord. This can be interpreted as due to partial resetting of pre-Caledonian material in the central part of the Caledonian fold belt.

Rex \& Gledhill (1973) from the University of Leeds have presented the results 
of $\mathrm{Rb} / \mathrm{Sr}$ whole rock isochron and $\mathrm{K} / \mathrm{Ar}$ mineral age determinations on material collected by a British expedition into Flyverfjord. They report K/Ar biotite and mineral ages from amphibolite pods in the basement gneisses ranging between 430 and 470 m.y. indicating a Caledonian thermal event in the area. A K/Ar muscovite age of 378 m.y. is interpreted as marking the end of Caledonian thermal and tectonic activity. The $\mathrm{Rb} / \mathrm{Sr}$ whole rock results yield a rather disturbed isochron giving an age of $3000 \pm 250 \mathrm{~m}$.y. suggesting that the pre-Caledonian basement in the area is Archaean.

\section{(15) Liverpool Land, East Greenland}

$\mathrm{Rb} / \mathrm{Sr}$ and $\mathrm{U} / \mathrm{Pb}$ studies are now in progress by $\mathrm{O}$. van Breemen and his colleagues at the Scottish Universities Research and Reactor Centre on material collected from Liverpool Land which forms the easternmost part of the Caledonian fold belt exposed in the Scoresby Sund region. Earlier $\mathrm{K} / \mathrm{Ar}$ and $\mathrm{Rb} / \mathrm{Sr}$ mineral ages carried out at E. T. H. on rocks from this area show that Liverpool Land contains considerable pre-Caledonian material reworked in the Caledonian orogeny as well as major Caledonian plutonic complexes.

\section{(16) Pre-Caledonian gneisses from Danmarkshavn, East Greenland}

$\mathrm{Rb} / \mathrm{Sr}$ whole rock isochron and mineral age determinations, U-Th-Pb determinations on zircon and sphene, and $\mathrm{K} / \mathrm{Ar}$ mineral ages are reported by Steiger et al. (in prep.) on a suite of gneissose rocks collected from Danmarkshavn, East Greenland. These detailed studies were carried out at E. T. H. in an attempt to date the Carolinidian orogeny, a N-S trending fold belt in East Greenland described by Haller (1971), which has been partly reworked by Caledonian tectonism and metamorphism. The $\mathrm{Rb} / \mathrm{Sr}$ whole rock and $\mathrm{U}-\mathrm{Th}-\mathrm{Pb}$ zircon ages together with some of the U-Th- $\mathrm{Pb}$ sphene ages record an event approximately 3000 m.y. ago in these rocks, while the $\mathrm{Rb} / \mathrm{Sr}$ and $\mathrm{K} / \mathrm{Ar}$ mineral ages together with the $\mathrm{U}$ $\mathrm{Th}-\mathrm{Pb}$ analysis on sphene show a thermal event which partly reset the isotopic systems approximately $320-380$ m.y. ago in this area.

\section{References}

Baadsgaard, $\mathrm{H}$. 1973: U-Th-Pb dates on zircons from the early Precambrian Amitsoq gneisses, Godthaab district, West Greenland. Earth planet. Sci. Lett. 19, 22-28.

Breemen, O. van, Allaart, J. H. \& Aftalion, M. in press: Isotopic and geochronological studies on granitic rocks in the early Proterozoic mobile belt of South Greenland. MS submitted to the Bull. geol. Soc. Amer.

Breemen, O. van \& Upton, B. G. J. 1972: The age of some Gardar intrusive complexes, Greenland. Bull. geol. Soc. Amer. 83, 3381-3390.

Bridgwater, D. \& Watterson, J. S. 1967: Igneous intrusions and associated rocks of the mangerite-charnockite suite. Nature, Lond. 213, 879 only.

Dawes, P. R. 1970: Bedrock geology of the nunataks and semi-nunataks in the Frederikshåbs Isblink area of southern West Greenland. Rapp. Grønlands geol. Unders. 29, $60 \mathrm{pp}$.

Escher, A., Escher, J. [C.] \& Watterson, J. [S.] 1970: The Nagssugtoqidian boundary and 
the deformation of the Kangâmiut dyke swarm in the Søndre Strømfjord area. Rapp. Grønlands geol. Unders. 28, 21-23.

Escher, A., Escher, J. C. \& Watterson, J. [S.] in press: The reorientation of the Kangâmiut dyke swarm, West Greenland. MS submitted to Can. J. Earth Sci.

Gulson, B. L. \& Krogh, T. E. 1972: U/Pb zircon studies on the age and origin of posttectonic intrusions from South Greenland. Rapp. Grønlands geol. Unders. 45, 48-53.

Haller, J. 1971: Geology of the East Greenland Caledonides. Interscience, 413 pp.

Haller, J. \& Kulp, J. L. 1962: Absolute age determinations in East Greenland. Meddr Grønland 171, 1, 77 pp.

Hansen, B. T., Steiger, R. H. \& Henriksen, N. 1972: The geochronology of the Scoresby Sund area. Progress report 2: $\mathrm{Rb} / \mathrm{Sr}$ mineral ages. Rapp. Grønlands geol. Unders. 48, 105-107.

Henderson, G. \& Pulvertaft, T. C. R. 1967: The stratigraphy and structure of the Precambrian rocks of the Umanak area, West Greenland. Meddr dansk geol. Foren. 17, 1-20.

Henderson, G. 1973: The implications of continental drift for the petroleum prospects of West Greenland. In Tarling, D. H. \& Runcorn, S. K. (edit.) Implications of continental drift to the earth sciences 1, 599-608. Edinburgh: Academic Press.

Larsen, O. \& Møller J. 1968: K/Ar age determinations from western Greenland. I. Reconnaissance programme. Rapp. Grønlands geol. Unders. 15, 82-86.

McGregor, V. R. 1973: The early Precambrian gneisses of the Godthåb district, West Greenland. Phil. Trans R. Soc. Lond. A, 273, 343-358.

Moorbath, S., O'Nions, R. K., Pankhurst, R. J., Gale, N. H. \& McGregor, V. R. 1972: Further Rubidium-Strontium age determinations on the very early Precambrian rocks of the Godthaab district, West Greenland. Nature phys. Sci., Lond. 240, 78-82.

Nunes, P. D., Steiger, R. H. \& Bridgwater, D. in prep: A zircon age from gabbro-anorthosite inclusions in the gneisses of the Angmagssalik area, South-East Greenland. MS prepared for publication in Rapp. Grønlands geol. Unders.

Oberli, F. \& Steiger, R. H. 1972: U-Pb systematics of zircons from a migmatite area. Abstract of paper read at the 2nd European colloquium of geochronology, Heidelberg, 1972.

Oxford Isotope Geology Laboratory \& McGregor, V. R. 1971: Isotopic dating of very early Precambrian amphibolite facies gneisses from the Godthaab district, West Greenland. Earth planet. Sci. Lett. 12, 245-259.

Pankhurst, R. J., Moorbath, S. \& McGregor, V. R. 1973: A late (ca. 3000 m. y.) event in the geological evolution of the Godthåb district, West Greenland. MS submitted to Nature, London.

Pidgeon, R. T. 1973: Discordant U-Pb isotopic systems in zircons from a granite north-west of Frederikshåbs Isblink, Fiskenæsset region. Rapp. Grønlands geol. Unders. 51, 28-30.

Rex, D. C. \& Gledhill, A (in press): Reconnaissance geochronology of the infracrustal rocks of Flyverfjord, Scoresby Sund, East Greenland. MS submitted to Bull. geol. Soc. Denmark.

Steck, A. 1971: Kaledonische metamorphose der praekambrischen Charcot Land Serie, Scoresby Sund, Ost-Grönland. Bull. Grønlands geol. Unders. 97, 69 pp.

Steiger, R. H. \& Henriksen, N. 1972: The geochronology of the Scoresby Sund area. Progress report 3: Zircon ages. Rapp. Grønlands geol. Unders. 48, 109-114.

Steiger, R. H., Soptrajanova, G., Zimmermann, E. \& Henriksen, N. in prep: Isotopic age and metamorphic history of the banded gneiss at Danmarkshavn, East Greenland. MS prepared for publication. 